\title{
Anthocyanin intake and Arterial Stiffness: A Literature Review
}

\author{
Tainah Ortiz ${ }^{1}$, Fernanda Gorski ${ }^{1}$, Eduardo Barbosa ${ }^{1,2}$ and Alexandre Machado Lehnen ${ }^{1 *}$ \\ ${ }^{1}$ Institute of Cardiology of Rio Grande do Sul/University Foundation of Cardiology, Brazil \\ ${ }^{2}$ Hypertension League of Porto Alegre, Brazil
}

Submission: July 18, 2019; Published: August 08, 2019

*Corresponding author: Alexandre Machado Lehnen, Instituto de Cardiologia do Rio Grande do Sul - Unidade de Pesquisa, Av. Princesa Isabel, 395, Santana. CEP 90620 001. Porto Alegre - RS Brazil

\begin{abstract}
There is a well-established association between aging, arterial stiffness, endothelial dysfunction, oxidative stress and the ensuing increased cardiovascular risk. Agents with antioxidant activity can improve endothelial function and arterial stiffness. Açaí-juçara is a fruit rich in anthocyanins, which are powerful antioxidants, and its daily consumption may have beneficial effects on vascular health, especially on central pulse pressure and pulse wave velocity. As anthocyanins may improve vascular health, especially central pulse pressure, dietary intake of anthocyanin-rich foods may reduce cardiovascular risk. Thus, this study aimed to review the effects of dietary intake of anthocyanins and its potential associations with central blood pressure improvement in overweight and obese individuals.
\end{abstract}

Keywords: Arterial stiffness; Hyperinsulinemia; Hypertriglyceridemia; Cardiovascular diseases; Cholesterol

Abbreviations: WHO: World Health Organization; PWV: Pulse Wave Velocity; ROS: Reactive Oxygen Species; CRP: C-reactive Protein; CPP: Central Pulse Pressure; SBP: Systolic Blood Pressure; DBP: Diastolic Blood Pressure; DRI: Dietary Reference Intake

\section{Introduction}

The prevalence of overweight and obesity has increased exponentially in recent years. Obesity is characterized by excess accumulation of body fat and is associated with increased risk of morbidity and mortality [1]. According to data from World Health Organization (WHO), in 2016, 39\% of women and 39\% of men aged 18 and over were overweight [2].

Obesity is strongly associated with cardiovascular outcomes. The mechanisms involved are complex and multifactorial. Some researchers suggest that obesity is a clinical condition associated with a low-intensity inflammatory state resulting from an imbalance between pro- and anti-inflammatory molecules due to increased production of pro-inflammatory molecules. Besides, visceral adiposity, glucose intolerance, hyperinsulinemia, hypertriglyceridemia and oxidative stress can lead to changes in vascular function [3]. It is thus important to identify individuals with accelerated vascular aging for early specific interventions targeting multiple risk factors [4].

Changes in vascular function can be assessed through pulse wave analysis. Pulse Wave Velocity (PWV) is an earlier marker of vascular wall changes [5] and it can be measured by applanation tonometry and an oscillometric method.

Experimental, epidemiological and clinical studies have shown that consumption of bioactive compounds present in fruits can decrease the oxidative damage and inflammation due to their antioxidant activity. The dietary intake of antioxidants can protect the body against the harmful effects of oxygen radicals with a positive impact on several chronic conditions including obesity, diabetes and neurodegenerative and cardiovascular diseases, and may improve endothelial function [6,7].

Açaí-juçara is the fruit of a Juçara palm tree (Euterpe Edulis Martius) that is rich in antioxidants, especially anthocyanins [8]. Recent studies of anthocyanin-rich extracts have shown their potential antioxidant role with significant reduction of blood pressure, strong anti-inflammatory activity and decrease of oxidative stress [6,7]. Although daily intake of açaí may have cardiovascular benefits, its impact on central blood pressure parameters is still controversial. Thus, our study aimed to review the effects of anthocyanin intake and its potential associations with central blood pressure improvement in overweight and 
obese individuals.

\section{Free radicals and oxidative stress}

Free radicals and Reactive Oxygen Species (ROS) are the products of normal cellular metabolism. They are good for the body and are involved in intercellular and intracellular signaling as well as in the synthesis of major biological substances. However, when the body is in an inflammatory state, ROS production is exacerbated. Increased generation of ROS is a consequence of body fat accumulation and may cause vascular damage leading to endothelial dysfunction and increased atheroma plaque formation and peripheral vascular resistance [9]. This state, without an adequate antioxidant response, can result in lipid peroxidation of cellular membrane and oxidative stress $[10,11]$.

The oxidative process causes damage to cells that progressively lose their function and become apoptotic [12]. Apoptosis in liver cells or neurons in the hypothalamus impairs metabolic functions due to an imbalance in the control of hunger/satiety and may cause energetic imbalance and, consequently, lead to obesity $[13,14]$.

\section{Vascular endothelium}

The endothelium is the cellular lining of the vascular wall that has important functions such as vascular tonus regulation and blood vessel protection. This protection occurs by a physiological stimulus causing shear stress, i.e., when blood flow exerts a frictional force on the endothelial cells, which increases blood vessel dilation capacity and nitric oxide bioavailability [15].

Increased serum levels of inflammatory markers such as interleukin-6 (IL-6) and C-reactive Protein (CRP) may cause a reduction (downregulation) in nitric oxide production due to inhibition of endothelial nitric oxide synthase. This downregulation facilitates atheroma plaque formation and, consequently, increases cardiovascular risk $[16,17]$.

\section{Arterial stiffness and vascular aging}

In addition to endocrine, inflammatory and vasoactive endothelium-derived components, the vessel wall has structural components that also play a role in vascular stiffening since an imbalance in the synthesis of collagen and/or elastin may contribute to decreased vascular distensibility [18].

Several studies have shown the relationship between oxidative stress and free radical production in the pathophysiology of vascular aging [19]. Recently, it has been suggested that vascular dysfunction along with increased arterial stiffness may be associated with obesity and cardiovascular diseases. Some researchers have reported increased arterial stiffness in obese adults and children when compared with eutrophic individuals [20-22].

Indirect methods have been proposed for assessing vascular aging. PWV measurement is the current gold-standard to assess arterial stiffness. Epidemiological evidence shows PWV is a predictor of cardiovascular events/diseases [23]. The pressurearea relation of the cross-sectional area of an artery in response to transmural pressure changes is a linear representation (PWV $=0$ ), which indicates arterial elasticity [24]. A curvilinear tracing denotes loss of arterial elasticity when PWV is $>0$ and is consistent with vascular stiffness. Hence, PWV is a measurement used to assess arterial stiffness. Blood pressure values are associated with several aspects including flow pulsatility and pulsatile modulation, which are directly related to vascular compliance and arterial stiffness [25].

Central pulse pressure (cPP) is defined as the difference between central Systolic Blood Pressure (SBP) and central Diastolic Blood Pressure (DBP) and is determined by left ventricle blood ejection into the aorta. cPP is the pulsatile component of blood pressure curve; the static component is mean arterial pressure [26]. Furthermore, cPP is the summation of a forward wave coming from the heart (so-called incident wave) and a backward wave returning to the heart due vascular resistance $[27,28]$. As vascular resistance increases, PWV increases and the reflected wave occurs earlier resulting in increased SBP and decreased DBP [23,27,29].

\section{Antioxidant intervention: anthocyanins}

Dietary intake of phytochemical bioactive compounds such as antioxidants present in foods has been shown to reduce oxidative damage and decrease inflammation. The intake of antioxidants is believed to have positive effects on several chronic conditions including obesity, diabetes and neurodegenerative and cardiovascular diseases [30].

Endogenous antioxidants do not provide full protection of cell components and thus exogenous antioxidants that come from foods are essential for the prevention and repair of ROS damage [30-32]. The intake of foods rich in antioxidants can favorably affect lipid and glucose metabolism and contribute to reducing metabolic syndrome risk [33]. Studies have shown that frequent consumption of antioxidant foods may restore damage resulting from oxidative and inflammatory responses, improve vascular protection and decrease the risk of obesity-related conditions $[32,34]$.

Anthocyanins are natural red to purple pigments (phytochemicals) that have antioxidant activity. The antioxidant properties of these compounds are related to their phenolic structure that transfers electrons from hydrogen atoms of the hydroxyl group on the aromatic ring [35]. They act as both free radical "sequesters" and metal chelators, acting at initiation and propagation of oxidation [36]. They are extremely important for free radical defense mechanism in conjunction with other enzymatic (superoxide dismutase, catalase and glutathione peroxidase) and non-enzymatic defenses (ascorbic acid and alpha-tocopherol) [37]. 
There are no recommended Dietary Reference Intake (DRI) values for phytochemicals. It has been demonstrated that synthetic antioxidants can prevent or attenuate ROS harmful effects both in vivo and in vitro. Studies have reported anti-inflammatory, cardioprotective and anti-obesogenic benefits of dietary intake of phytochemical compounds, especially anthocyanins, in the human body $[6,7,38]$.

According to the European Food Safety Authority and FAO/ WHO Expert Committee on Food Additives (JECFA), the daily consumption of anthocyanins $(2.5 \mathrm{mg} / \mathrm{kg}$ body weight) is safe. In their review study, Pojer found that toxicity risks of dietary supplementation of anthocyanins are extremely low and even an intake of $160 \mathrm{mg}$ twice a day $(320 \mathrm{mg} /$ day) was well-tolerated with no reported side effects [39].

Fairlie-Jones et al. [40] conducted a meta-analysis of randomized controlled trials to assess the effect of anthocyaninrich extracts on vascular function in adults. Their results support the findings that anthocyanins may improve vascular health, especially flow-mediated dilation with acute and chronic supplementation and PWV with acute supplementation [40].

In a cross-sectional study of 1,898 women from the UK Adult Twin Registry (TwinsUK), higher anthocyanin intake was associated with significantly lower central SBP, lower PWV and reduced arterial stiffness [41].

\section{Açaí and berries}

Natural foods as antioxidant sources have gained increasing attention [42]. Açaí is a fruit rich in anthocyanins. There are two species: conventional açaí (Euterpe Oleracea Mart) and açaí-juçara from Juçara palm tree (Euterpe Edulis Martius). The dry matter content of açaí-juçara has high content of phenolic compounds, such as ellagic acid and anthocyanins, and exhibits potent antioxidant activity [43].

Anthocyanins found in the açaí-juçara pulp vary from $60 \mathrm{mg}$ to $410 \mathrm{mg} / 100 \mathrm{~g}$ wet matter and the antioxidant content shows seasonal and harvest area variation $[43,44]$. In addition to its high content of anthocyanins, açaí-juçara is a natural source of fibers, oleic and linolenic acid and other micronutrients such as vitamin E.

Many studies have evaluated the dose-response relationship and effects/effectiveness of antioxidant supplementation in the human body [45] and in animals [46]. It has been demonstrated that dietary supplementation of $2 \%$ and $6 \%$ lyophilized açaí in apolipoprotein E-deficient (ApoE -/-) mice improved their lipid profile and antioxidant defense and showed a hypoglycemic effect [46]. Another study found that dietary intake of anthocyanins at $0.90 \mathrm{mg} /$ day was associated with reduced risk of developing cardiovascular disease in post-menopausal women [47]. Significant lower levels of fasting plasma glucose, insulin, cholesterol, triglycerides, exhaled nitric oxide metabolites (breath) and ultra-sensitive plasma CRP (hs-CRP) were found in overweight individuals following a 30-day intake of $100 \mathrm{~mL}$ of açaí pulp twice a day [48]. Other studies have demonstrated reductions in fasting blood glucose and insulin levels, total cholesterol, LDLcholesterol and total cholesterol-to-HDL ratio and, therefore, reduced markers of metabolic syndrome risk $[32,34]$.

Furthermore, the consumption of açaí has been associated with decreased insulin and glucose levels in overweight men. Evidence shows that dietary intake of açaí containing approximately 690 $\mathrm{mg}$ of phenolics and anthocyanins is associated with improvement in vascular function. This benefit appears to be associated with improvement of redox status [49].

\section{Conclusion}

Structural degenerative damage of arterial elastic components is little reversible with drug therapies currently available. It is thus extremely important to assess the impact of preventive interventions for reducing vascular stiffness and accelerated vascular aging. Dietary intake of anthocyanin-rich foods has shown several health benefits and may reduce cardiovascular risks. The effects of anthocyanin intake, especially açaí-juçara, on central blood pressure parameters should be further investigated in randomized controlled trials to support the assumed benefits of arterial stiffness improvement.

\section{References}

1. Zalesin KC, Franklin BA, Miller WM, Peterson ED, McCullough PA (2011) Impact of obesity on cardiovascular disease. Med Clin North Am 95(5): 919-937.

2. WHO (2016) World Health Organization. Office of Library and Health Literature Services.

3. Keaney JF, Larson MG, Vasan RS, Wilson PW, Lipinka I, et al. (2003) Obesity and systemic oxidative stress: clinical correlates of oxidative stress in the Framingham Study. Arterioscler Thromb Vasc Biol 23(3): 434-439.

4. Mikael LR, Paiva AMG, Gomes MM, Sousa ALL, Jardim PCBV, et al. (2017) Vascular Aging and Arterial Stiffness. Arq Bras Cardiol 109(3): 253-258.

5. Hermeling E, Hoeks AP, Reneman RS, Segers P, Reesink KD (2012) Assessment of systolic and diastolic arterial stiffness. J Hypertens 30(7): 1489-1491; author reply 1491-1492.

6. Angel-Morales G, Noratto G, Mertens-Talcott S (2012) Red wine polyphenolics reduce the expression of inflammation markers in human colon-derived CCD-18Co myofibroblast cells: potential role of microRNA-126. Food Funct 3(7): 745-752.

7. Pascual-Teresa S, Moreno DA, Garcia-Viguera C (2010) Flavanols and anthocyanins in cardiovascular health: a review of current evidence. Int J Mol Sci 11(4): 1679-1703.

8. de Brito ES, de Araujo MC, Alves RE, Carkeet C, Clevidence BA, et al. (2007) Anthocyanins present in selected tropical fruits: acerola, jambolao, jussara, and guajiru. Journal of Agricultural and Food Chemistry 55(23): 9389-9394.

9. Berra CM, Menck, CF, Mascio PD (2006) Estresse oxidativo: lesões no genoma e processos de sinalização no controle do ciclo celular. Química Nova 29(6): 1340-1344.

10. McFarlane SI, Banerji M, Sowers JR (2001) Insulin resistance and cardiovascular disease. J Clin Endocrinol Metab 86(2): 713-718. 
11. Fichtlscherer S, Rosenberger G, Walter DH, Breuer S, Dimmeler S, et al. (2000) Elevated C-reactive protein levels and impaired endothelial vasoreactivity in patients with coronary artery disease. Circulation 102(9): 1000-1006.

12. Cohen JB, Stephens-Shields AJ, Denburg MR, Anderson AH, Townsend RR, et al. (2016) Obesity, Renin-Angiotensin System Blockade and Risk of Adverse Renal Outcomes: A Population-Based Cohort Study. Am J Nephrol 43(6): 431-440.

13. Milanski M, Degasperi G, Coope A, Morari J, Denis R, et al. (2009) Saturated fatty acids produce an inflammatory response predominantly through the activation of TLR4 signaling in hypothalamus: implications for the pathogenesis of obesity. J Neurosci 29(2): 359-370.

14. Moraes JC, Coope A, Morari J, Cintra D, Roman EA, et al. (2009) High-fat diet induces apoptosis of hypothalamic neurons. Plos One 4(4): e5045.

15. Machado BH, Bonagamba LG (1992) Microinjection of S-nitrosocysteine into the nucleus tractus solitarii of conscious rats decreases arterial pressure but L-glutamate does not. Eur J Pharmacol 221(1): 179-182.

16. Ramos AM, Pellanda LC, Gus I, Portal VL (2009) Inflammatory markers of cardiovascular disease in the elderly. Arq Bras Cardiol 92(3): 221228.

17. Libby P, Ridker PM, Maseri A (2002) Inflammation and atherosclerosis. Circulation 105(9): 1135-1143.

18. Johnson CP, Baugh R, Wilson CA, Burns J (2001) Age related changes in the tunica media of the vertebral artery: implications for the assessment of vessels injured by trauma. J Clin Pathol 54(2): 139-145.

19. Bastien M, Poirier P, Lemieux I, Despres JP (2014) Overview of epidemiology and contribution of obesity to cardiovascular disease. Prog Cardiovasc Dis 56(4): 369-381.

20. Sutton-Tyrrell K, Newman A, Simonsick EM, Havlik R, Pahor M, et al. (2001) Aortic stiffness is associated with visceral adiposity in older adults enrolled in the study of health, aging, and body composition. Hypertension 38(3): 429-433.

21. Wildman RP, Mackey RH, Bostom A, Thompson T, Sutton-Tyrrell K (2003) Measures of obesity are associated with vascular stiffness in young and older adults. Hypertension 42(4): 468-473.

22. Tounian P, Aggoun Y, Dubern B, Varille V, Guy-Grand B, et al. (2001) Presence of increased stiffness of the common carotid artery and endothelial dysfunction in severely obese children: a prospective study. Lancet 358(9291): 1400-1404.

23. Brandão AA, Amodeo C, Alcântara C, Barbosa E, Nobre F, et al. (2017) I Luso-Brazilian Positioning on Central Arterial Pressure. Arq Bras Cardiol 108(2): 100-108.

24. Hermeling E, Vermeersch SJ, Rietzschel ER, de Buyzere ML, Gillebert TC, et al. (2012) The change in arterial stiffness over the cardiac cycle rather than diastolic stiffness is independently associated with left ventricular mass index in healthy middle-aged individuals. J Hypertens 30(2): 396-402.

25. Veugen MG, Henry RM, van Sloten TT, Hermeling E, Brunner-La Rocca HP, et al. (2017) The systolic-diastolic difference in carotid stiffness is increased in type 2 diabetes: The Maastricht Study. J Hypertens 35(5): 1052-1060.

26. Safar ME (1989) Pulse pressure in essential hypertension: clinical and therapeutical implications. J Hypertens 7(10): 769-776.

27. Veerasamy M, Ford GA, Neely D, Bagnall A, MacGowan G, et al. (2014) Association of Aging, Arterial Stiffness, and Cardiovascular Disease: A Review. Cardiol Rev 22(5): 223-232.

28. Franklin SS, Gustin W, Wong ND, Larson MG, Weber MA, et al. (1997) Hemodynamic patterns of age-related changes in blood pressure. The
Framingham Heart Study. Circulation 96(1): 308-315.

29. Costa AGV, Garcia-Diaz DF, Jimenez P, Silva PI (2013) Bioactive compounds and health benefits of exotic tropical red-black berries. Journal of Functional Foods 5(2): 539-549.

30. Cerqueira FM, Medeiros, MHG, Augusto O (2007) Antioxidantes dietéticos: controvérsias e perspectivas. Quím Nova 30(2): 441-449.

31. Andrade CA, Costa CK, Bora K, Miguel MD, Miguel OG, et al. (2007) Determinação do conteúdo fenólico e avaliação da atividade antioxidante de Acacia podalyriifolia. Rev Bras Farmacogn 17(2): 231235.

32. Sacheck J (2008) Pedriatric obesity: an inflammatory condition? JPEN J parenter Enteral Nutr 32(6): 633-637.

33. Dembinska-Kiec A, Mykkanen O, Kiec-Wilk B, Mykkanen H (2008) Antioxidant phytochemicals against type 2 diabetes. Br J Nutr 99(E Suppl 1): 109-117.

34. Lima CP, Cunico MM, Miyazaki CMS, Miguel OG, Côcco LC, et al. (2012) Conteúdo polifenólico e atividade antioxidante dos frutos da palmeira Juçara (Euterpe Edulis Martius). Revista Brasileira de Plantas Medicinais 14(2): 321-326.

35. Rice-Evans CA, Miller NJ, Paganga G (1996) Structure-antioxidant activity relationships of flavonoids and phenolic acids. Free Radic Biol Med 20(7): 933-956.

36. Cataneo CB (2008) Atividade antioxidante e conteúdo fenólico do resíduo agroindustrial da produção de vinho. Semina 29(1): 93-102.

37. Volp ACP, Renhe IRL, Barra K, Stringueta PC (2008) Flavonóides antocianinas: características e propriedades na nutrição e saúde. Rev Bras Clin 23(2): 141-149.

38. Tsuda T, Ueno Y, Kojo H, Yoshikawa T, Osawa T (2005) Gene expression profile of isolated rat adipocytes treated with anthocyanins. Biochimica et Biophysica Acta 1733(2-3): 137-147.

39. Pojer E, Mattivi F, Johnson D, Stockley CS (2013) The case for anthocyanin consumption to promote human health: A review. Comprehensive Review. Food Science and Food Safety 12(5): 483-508.

40. Fairlie-Jones L, Davison K, Fromentin E, Hill AM (2017) The Effect of Anthocyanin-Rich Foods or Extracts on Vascular Function in Adults: A Systematic Review and Meta-Analysis of Randomised Controlled Trials. Nutrients 9(8): E908.

41. Jennings A, Welch AA, Fairweather-Tait SJ, Kay C, Minihane AM, et al. (2012) Higher anthocyanin intake is associated with lower arterial stiffness and central blood pressure in women. Am J Clin Nutr 96(4): 781-788.

42. Mauray A, Milenkovic D, Besson C, Caccia N, Morand C, et al. (2009) Atheroprotective effects of bilberry extracts in Apo-E-deficient mice. J Agric Food Chem 57(23): 11106-11111.

43. Costa GNS, Mendes MF, Araújo IM, Pereira CSS (2012) Desenvolvimento de um iogurte sabor juçaí (Euterpe Edulis Martius): avaliação físicoquímica e sensorial. Revista eletrônica TECCEN 5(2): 43-58.

44. Borges GSC, Vieira GCK, Copetti C, Gonzaga LV, Zambiazi RC, et al. (2011) Chemical characterization, bioactive compounds, and antioxidante capacity of jussara (Euterpe Edulis) fruit from the Atlantic forest in Southern Brazil. Food Research International 44(7): 2128-2133.

45. Huber K (2016) Avaliação de Produto Diet a Base de Açaí Juçara (Euterpe Edulis Martius) e seus efeitos antiobesogênico, anti-inflamatório e antioxidante em adolescentes obesos. Tese de Doutorado. Unicamp. Faculdade de Engenharia de Alimentos. Campinas.

46. Novello AA (2011) Extração de antocianinas dos frutos do açai da Mata Atlântica (Euterpe Edulis Martius) e sua atuação nas atividades antioxidante e antiaterogênica em camundongos ApoE -/-. Dissertação 
de Mestrado. Universidade Federal de Viçosa, Viçosa.

47. Mink PJ, Scrafford CG, Barraj LM, Harnack L, Hong CP, et al. (2007) Flavonoid intake and cardiovascular disease mortality: a prospective study in postmenopausal women. The American Journal of Clinical Nutrition 85(3): 895-909.

48. Udani JK, Singh BB, Singh VJ, Barrett ML (2011) Effects of Açai (Euterpe Oleracea Mart) berry preparation on metabolic parameters in a healthy overweight population: a pilot study. Nutr J 10: 45.

49. Alqurashi RM, Galante LA, Rowland IR, Spencer JPE, Commane DM
(2016) Consumption of a flavonoid-rich açaí meal is associated with acute improvements in vascular function and a reduction in total oxidative status in healthy overweight men. Am J Clin Nutr 104(5): 1227-1235.

Your next submission with Juniper Publishers
will reach you the below assets
- Quality Editorial service
- Swift Peer Review
- Reprints availability
- E-prints Service
- Manuscript Podcast for convenient understanding
- Global attainment for your research
- Manuscript accessibility in different formats
( Pdf, E-pub, Full Text, Audio)
- Unceasing customer service
Track the below URL for one-step submission
https://juniperpublishers.com/online-submission.php

